УДК 372

DOI: 10.37026/2520-6427-2019-99-3-136-140
Олександра СОКОЛОВСЬКА,

докторка філософії в галузі освіти, дочентка кафедри дошкільної освіти Миколаївського національного університету імені В. О. Сухомлинського

\title{
НОВА УКРАЇНСЬКА ШКОЛА - «ШКОЛА РАДОСТІ» НА ЗАСАДАХ ПЕДАГОГІЧНИХ ІДЕЙ ВАСИЛЯ СУХОМЛИНСЬКОГО
}

У статті розкривається сутність поняття «нова украӥнська школа», розглядається проблема формування позитивної мотивації школярів у навчанні і розвитку. На прикладі педагогічних ідей Василя Сухомлинського аналізуються різні підходи у сприянні самовизначення школярів. Виявлені особливості проиесу взаємозв'язку загальноосвітньої школи та їі сочіальних партнерів у реалізаиії освітньої проєктної діяльності учнів. Обгрунтовується необхідність виховання здорової дитини в процесі навчання, щзо передбачає тісний зв'язок між усіма сторонами даного проиесу, урахування індивідуальних особливостей кожної дитини, створення ситуаиії успіху $i$ радості для дітей.

Ключові слова: педагогічна спадщчина Василя Сухомлинського, школа радості, обдаровані діти, талановиті діти, самовизначення, сочіально-культурні практики.

В статье раскрывается сущность понятия «новая украинская школа», рассматривается проблема формирования положительной мотивации школьников в обучении и развитии. На примере педагогических идей Василия Сухомлинского анализируются различные подходы в содействии самоопределения школьников. Выявлены особенности процесса взаимосвязи общеобразовательной школь и ее сочиальных партнеров в реализаччи образовательной проектной деятельности учашихся. Обосновывается необходимость воспитания здорового ребенка в прочессе обучения, предусматривает тесную связь между всеми сторонами данного процесса, учета индивидуальных особенностей каждого ребенка, создание ситуации успеха и радости для детей.

Ключевые слова: педагогическое наследие Василия Сухомлинского, школа радости, одаренные дети, талантливые дети, самоопределение, социально-культурные практики.

The article reveals the essence of the concept «New School», the problem of formation of positive motivation of students in education and development are considered. On the example of Vasyl Sukhomlynsky's pedagogical ideas, various approaches are employed to promote self-determination of schoolchildren. Features of process of interrelation of comprehensive school and its social partners in realization of educational design activity of pupils are found. The necessity of raising a healthy child in the process of education is substantiated, which implies a close connection between all sides of this process, taking into account the individual characteristics of each child, creating a situation of success and joy for children.

Changes occurring in society significantly affect the process of shaping the social experience of children. The development of our society depends on what values will be formed in children today, how young the generation will be prepared for a new type of social relations.

The world we live in now is changing much faster than before. The speed of change is so high that one sometimes does not have time to adjust to one's realities as one enters into another. New generations of children are emerging as fast as we can now. Only the Z-generation features were discussed at the pedagogical meetings. "Digital» children, intentions, as they are called, feel equally comfortable in the real and virtual environment, they do not feel the difference between them. The digital generation is pragmatic, does not like to do something that does not provide specific benefits. They are looking for optimal ways to reach the goal, even as they learn new professions through the Internet.

Key words: the pedagogical heritage of Vasily Sukhomlinsky, school of joy, gifted children, talented children, self-determination, socio-cultural practices.

Постановка проблеми. Соціально-економічне реформування системи освіти в умовах перебудови державності, відродження культурних надбань та духовності суспільства потребує вдосконалення процесу навчання і виховання дітей.

Зміни, що відбуваються в суспільстві, істотно впливають на процес формування соціального досвіду дітей. Від того, які цінності будуть сформовані в дітей сьогодні, від того, наскільки молоде покоління буде готове до нового типу соціальних відносин, залежить розвиток нашого суспільства. Дитина вбирає впливи навколишнього середовища, включаючись у спільну з іншими людьми діяльність та отримуючи від цього радість. Природа людської радості багатогранна, має протиріччя й пізнана у своїх глибинах. Радість найчастіше супроводжує неочікуваність та невідповідність. Радісний стан характеризується неймовірною кількістю відтінків: посмішкою, іронією, 
самоіронією, сарказмом, жартами. Радість є ситуативною. Інколи, самі того не помічаючи, ми за декілька хвилин можемо змінювати наш емоційний стан від гніву до радості. Відчуття радості тісно пов'язане 3 контекстом часу. Світ, в якому ми живемо, змінюється значно швидше, ніж раніше. Швидкість змін настільки висока, що людина інколи не встигає пристосуватися до одних реалій, як уже вступає в інші. Так само швидко в наш час 3'являються і нові покоління дітей. Нещодавно на педагогічних зібраннях обговорювалися особливості покоління «Z» - «цифрові» діти, інтеніали, як прийнято їх називати, однаково комфортно почуваються в реальному й віртуальному середовищі, вони не відчувають між ними різниці. Цифрове покоління прагматичне, не любить займатися тим, що не передбачає конкретної користі. Вони шукають оптимальні шляхи досягнення мети, навіть нові професії освоюють через мережу Інтернет. Педагоги ще не встигли зрозуміти всі особливості інтеніалів, а вже почали з'являтися публікації про покоління «Саторі». Японські вчені перші заговорили про цих дітей. Це покоління, яке до мінімуму звело свої потреби. Це діти, яким нічого не треба. Вони не займаються спортом, не хочуть подорожувати, їх не цікавить кар'єрний ріст, вони поступаються і намагаються йти шляхом із найменшими ускладненнями. До матеріальних збагачень теж пасивні. Не зважають і на те, що їх утримують батьки, при цьому більше за все цінують свободу. Вільний доступ до будь-якої інформації і можливість без перешкод іiі отримати підштовхнули їх до розуміння, що в сучасному світі легше виключити себе зі змагання, довівши потреби до мінімуму, але отримати високий ступінь свободи.

Виникає низка запитань: «Як побудувати «школу радості» 3 тими, кому нічого нецікаво?», «Як займатися розвитком тих, хто не бажає розвиватися?», «Що робити з поколінням байдужих?».

Досвід та практика свідчать про те, що на сьогодні кількість обдарованих дітей та дітей із високим інтелектуальним потенціалом зросла.

Ті педагогічні теорії, що спрацьовували раніше, не працюють зараз. Проте незмінним залишається значення для розвитку дитини оточуюче середовище. Середовище спрацьовує тоді, коли воно будується людиною самостійно. Учень сам має формувати своє середовище перебування, знаходити друзів, обирати коло спілкування, відвідувати гуртки, секції, які йому цікаві. Роль дорослого при цьому - підтримувати, допомагати, сприяти отриманню соціального досвіду. Ключовою складовою психолого-педагогічного механізму соціального досвіду є діяльність (Л. Виготський, М. Коган, О. Леонтьєв). Вона являє собою спосіб, умову, форму вираження культурно-історичного відтворення соціального досвіду. Нагромадження дитиною самостійно й під керівництвом дорослих соціального досвіду сприяє розкриттю вікового потенціалу, успішному навчанню в школі, а пізніше надає можливість реалізувати свої здібності і набуті знання в дорослому житті.

Майбутнє людської цивілізації залежить від реалізації обдарованості людей. Тому виникає потреба в особливій увазі до обдарованих дітей та дітей із високим інтелектуальним потенціалом.

Аналіз наукових досліджень та публікацій. Проблеми модернізації педагогічної освіти висвітлені у працях таких учених, як В. Андющенко, А. Богуш, В. Бондар, І. Зязюн, Н. Кічук, Л. Кондрашова, С. Литвиненко, В. Сластьонін та ін. Дослідниками розкрито зміст, структуру професійно-педагогічної готовності майбутніх учителів у різних напрямах освіти до роботи 3 дітьми різної готовності до навчання в школі.

До кола наукових інтересів учених (М. Данілов, П. Підкасистий, І. Підласий, О. Савченко, Т. Шамова) увійшли й проблеми організації роботи 3 обдарованими учнями. Розвитку інтелектуальної обдарованості присвячено роботи таких вітчизняних учених, як Г. Ващенко, Л. Виготський, В. Вернадський, М. Гончаров, О. Леонтьєв, І. Огієнко, С. Рубінштейн.

Особистість В. Сухомлинського та окремі аспекти його педагогічної спадщини стали предметом вивчення науковців як в Україні (М. Антонець, I. Бех, А. Богуш, Л. Бондар, І. Зязюн, В. Кузь, О. Савченко, М. Сметанський), так і за ії межами (А. Борисовський, Б. Кваша, М. Мухін, В. Риндак). Роботи видатного педагога досліджували Х. Франчос і М. Ціандзі (Греція), Р. Штайник, Е. Гартман (Німеччина), М. Библюк, С. Лашин (Польща), Л. Мілков (Болгарія), Бі Шудєжі, Ван Ігосо (Китай), А. Кокеріль (Австралія).

Мета статті полягає у визначенні місця і ролі педагогічної спадщини Василя Сухомлинського в освітньому просторі нової української школи.

Виклад основного матеріалу. Зважаючи на аналіз наукової літератури, необхідність пошуку засобів, методів виховання дітей в процесі навчання у новій українській школі зумовило потребу в зверненні до історико-педагогічної спадщини. Значний внесок у розвиток цієї проблеми зробив видатний педагог, новатор та мислитель Василь Сухомлинський. Розроблена вченим система формування, виховання і розвитку особистості дитини грунтувалася на глибокій турботі про дітей із різним рівнем розвитку, відношення до навчання, зміцнення здоров'я кожного вихованця, гармонізації фізичного і духовного розвитку. У зв'язку з цим особливу увагу він приділяє такому аспекту, як радість навчання, радість пізнання, творчість, що сприяє емоційному комфорту, розкриттю розумового потенціалу кожної дитини. Навчання має бути і серйозною робою, і радісною працею, що укріплює духовні і фізичні сили дитини [3].

У своїй діяльності педагог-новатор використовує індивідуально-диференційований підхід та виокремлює важко успішних, високообдарованих $i$ дітей із середніми здібностями. Останні діляться на три групи: перша - це старанні учні, самостійно справляються 3 навчальними завданнями та для яких успішне виконання завдання пов'язане 3 певним напруженням розумових сил, із пошуком, подоланням труднощів; друга - діти, які без сторонньої допомоги справляються із завданнями середньої важкості, однак складні завдання іноді не можуть виконати; третя група - учні, які повільно осмислюють та вирішують завдання, тобто повільні учні, їм необхідна не так стороння допомога, як значно більша кількість часу [3]. Така диференціація давала можливість кожному учневі з урахуванням його психологічних і фізіологічних особливостей переживати радість успіху в навчанні, що є необхідною умовою комфортної і продуктивної навчальної діяльності.

Посилаючись на наукові праці та багаторічний практичний досвід ученого, для дослідження поставленої мети ми провели анкетування серед студентів IV курсу факультету дошкільної та початкової освіти спеціальності «початкова освіта», що перебували на педагогічній практиці в різних школах міста Миколаєва. Аби краще розібратися, які проблеми виникли у студентів під час проходження практики у класах, 
де діти навчаються за моделлю нової української школи, ми розробили спеціальні анкети. В анкетуванні взяли участь 43 студенти. 3'ясувалося, що в класах були такі діти: здібні; обдаровані; з високим рівнем інтелекту (ЗОШ № 22); діти старанні, де здійснюється контроль з боку батьків; діти, яким комфортно перебувати як у реальному, так і віртуальному середовищі (1\%); діти, в яких відсутня мотивація до навчання $(0,5 \%)$; діти з особливими потребами $(0,3 \%)$.

Це спонукало нас ускладнити роботу. В університеті щорічно проводиться конкурс студентських творчих робіт, до якого включили написання есе, розробку моделей, макетів нової української школи. Студенти 3 науковим обгрунтуванням творчо підходили до виконання робіт.

На думку Марини Я., «практика дала багато: знайомство 3 повсякденною працею вчителя, відпрацювання навичок роботи перед аудиторією, взаємодії $з$ дітьми, розуміння того, що неможливо бути гарним педагогом без глибоких знань педагогіки, психології, історії нашого народу, нашої країни».

Ганна Ш. зауважує: «Практика в школі - час відкриття (відкриття себе і своїх можливостей насамперед)».

Ірина Т. серед причин негативного ставлення дітей до навчання в школі називає нецікаве викладання матеріалу і відсутність успіхів у навчальній діяльності, неможливість уникнення конфлікту з учителем. Школа не завжди дає можливість творчо проявити себе та не завжди враховує інтереси учня. «Ці факти спонукають задуматися над тим, як у своїй педагогічній діяльності цьому запобігти», - пише Ірина.

У своїх творчих роботах студенти наголошують, що сучасний учитель саме нової української школи повинен «уміти спілкуватися», «вміти впливати на тих, хто навчається», «бути комунікативним», «налагоджувати стосунки з батьками» i, що найважливіше, працювати 3 дітьми нового покоління.

Зважаючи на викладене вище, саме оновлена система освіти, на нашу думку, не дозволить учителю зупинитися у своєму розвитку і стати нецікавим учням у новій українській школі.

У школах необхідно переглянути роботу методичних об'єднань: замість відкритих уроків та виставок проводити презентації робіт учителів-аналітиків, результатів учнівських робіт, демонструвати підготовчу роботу над проєктами в роботі з обдарованими дітьми та дітьми із особливими потребами.

Однак треба не забувати, що нова школа - це i джерело духовності. Нова школа - це інститут освіти та виховання, де присутня контрактна система, яка базується на освітньому ландшафті й традиціях шкільної освіти (культурна, громадянська, здоров'я і спорт). Нова українська школа - це школа, в якій сформовано розвиваюче освітнє середовище і створена доброзичлива атмосфера, де поважають інтереси і реалізуються очікування всіх учасників освітнього процесу.

Із метою глибокого розуміння сучасного освітнього процесу під час практичних занять в університеті, гурткової роботи, засідань студентської наукової групи пропонуємо більш поглиблене вивчення педагогічної спадщини видатного вченого Василя Сухомлинського.

Варто наголосити, що казки, оповідання, наукові праці, архівні матеріали українського педагога достатньо широко використовуємо в практиці професійної самореалізації студентів факультету дошкільної та початкової освіти. Пропонуємо для обговорення та вивчення такі праці В. Сухомлинського:
«Людина неповторна», «Моральні заповіді дитинства і юнацтва», «Серце віддаю дітям», «Школа радості», «Шлях до серця дитини», «Як виховати справжню людину», «Проблема виховання всебічно розвиненої особистості».

Педагогічні праці видатного вченого тією чи іншою мірою присвячені питанням дитячої обдарованості.

Раннє виявлення, навчання та виховання обдарованих і талановитих дітей є однією із найважливіших проблем, яку вивчає В. Сухомлинський. На його думку, обдаровані діти потребують допомоги дорослих, особливої уваги і керівництва їх навчальною діяльністю.

У силу індивідуальних особливостей вони найбільш чутливі до оцінки своєї діяльності, поведінки і мислення, більш сприйнятливі до сенсорних стимулів і краще відчувають відносини та зв'язки.

Як стверджує вчений, не існує нездібних, бездарних і лінивих дітей. «У кожної людини, - пише Василь Олександрович у статті «Людина неповторна», $є$ задатки обдаровання, талант до певного виду або кількох видів (галузей) діяльності» [3, с. 88].

Педагог-практик акцентує увагу на необхідності розвивати здібності і талант усіх без винятку дітей, що прийшли до школи. «Ми глибоко переконані в тому, що немає людини, яка в належних умовах за вмілого виховання не виявила б свого самобутнього, неповторного таланту. П'ятсот вихованців, духовне обличчя яких ми повинні сформувати, - це п'ятсот неповторних талантів і обдаровань. Поважати в кожному учневі людину, виявляти до нього гуманне ставлення - це насамперед розкрити в ньому таку людську неповторність» [3, с. 88].

Він уважає, що обдарованість дітей може бути визначена і вивчена лише в процесі навчання і виховання, тобто під час виконання дитиною тієї чи іншої змістовної діяльності. Прояви розумової обдарованості в дитини обумовлені надзвичайними можливостями дитячого віку. Потрібно мати на увазі, що в молодшому шкільному віці стрімкий розумовий розвиток відбувається в усіх дітей, роблячи таким чином вирішальний внесок дитинства в становлення інтелекту.

Основна складність виявлення в дитинстві ознак обдарованості, на думку вченого, полягає в тому, що в них непросто виокремити власне індивідуальне, відносно незалежне від вікового. Так, висока розумова активність, яка спостерігається в дитини, особлива готовність до напруження - це внутрішня умова розумового зростання. I невідомо чи буде вона стійкою особливістю й на наступних вікових етапах. При цьому ранні прояви обдарованості ще не визначають майбутніх можливостей школяра: надзвичайно важко передбачити хід подальшого становлення обдарованості.

«Ми бачимо, - пише В. Сухомлинський у праці «Проблеми виховання всебічно розвиненої особистості», - що дискретність роботи мозку проявляється в дітей по-різному: в одного ця робота дуже швидка, в іншого - повільна, звідси - кмітливість і некмітливість, тямущість і нетямущість, міцність і неміцність пам'яті, сильно і слабко виражена здатність до оволодіння знаннями» [4, с. 98]. Саме на цих засадах необхідно будувати освітній процес у сучасній школі.

«Мистецтво та майстерність навчання й виховання полягає в тому, - як стверджує педагог-практик у праці «Сто порад учителеві», - щоб, розкривши сили і можливості кожної дитини, дати їй радість успіху 
в розумовій праці. А це означає, що в навчанні має бути індивідуалізація - і в змісті розумової праці (в характері завдань), і в часі. Досвідчений педагог дає одному учневі дві, три, а то й чотири задачі на урок, іншому жтільки одну. Один одержує складнішу задачу, інший простішу» [5, с. 437]. Головне, що за такого підходу діти просуваються вперед - одні швидше, інші - повільніше, але всі отримують радість від навчання.

Слід розрізняти також обдарованість і прискорення темпів розвитку дитини, яке може виявитися тимчасовим. Така «талановитість» швидко згасає, оскільки відсутній прояв творчого компонента або його розвиток був несвоєчасним. Іноді дитина є носі$\epsilon м$ «прихованої обдарованості» (відсутність яскраво виражених ознак талановитості), що може бути спричинене негативним ставленням дорослих до успіхів дитини або іiі побоюванням бути неправильно зрозумілою. Обдаровані діти наділені високим творчим потенціалом і рівнем розвитку здібностей.

«Своєчасно знайти, виховати і розвинути задатки здібностей у своїх вихованців, своєчасно розпізнати в кожному його покликання, - пише Василь Олександрович у статті «Розвиток індивідуальних здібностей і нахилів учнів», - це завдання тепер найголовніше у системі навчально-виховної роботи» [3, с. 123]. I найголовнішим у розв'язанні цього завдання, як наголошується у праці «Павлиська середня школа», «помітити в кожній дитині іiі найсильнішу сторону, знайти в ній ту «золоту жилку», від якої починається розвиток індивідуальності, домогтися того, щоб дитина досягла видатних для свого віку успіхів у тій справі, яка найбільш яскраво виявляє та розкриває іiі природні задатки» [5, с. 19].

Обдаровані діти часто $є$ оригінальними в поведінці та спілкуванні. Вони використовують особливі способи спілкування 3 дорослими й однолітками, чутливі до ситуації спілкування, виявляють уміння спілкуватися не лише словесно, а й за допомогою міміки, жестів, інтонації, легко вступають у контакт 3 однолітками, прагнуть до лідерства у спільній діяльності. Обдаровані діти частіше за своїх однолітків обирають роль дорослого в творчих іграх, змагаються 3 іншими дітьми. Також вони не бояться відповідальності, ставлять високі вимоги до себе, є самокритичними; не люблять, коли до них ставляться із захопленням, обговорюють їхню винятковість, талановитість. Ці діти випереджають однолітків у моральному розвитку, активно прагнуть добра, справедливості, правди, виявляють інтерес до всіх духовних цінностей. До ранніх виявів обдарованості дитини належать: потужна енергійність, значна фізична, розумова і пізнавальна активність, порівняно низькі втомлюваність та потреба у відпочинку; інтенсивний розвиток мовлення; допитливість, прагнення до експериментування; легке і швидке засвоювання та використання нової інформації.

На думку вченого-практика, складовими ранньої обдарованості є домінуюча роль пізнавальної мотивації; дослідницька творча активність, яка полягає у виявленні нового під час формулювання і розв'язання проблем; уміння знайти оригінальні рішення; здатність до прогнозування.

Багаторічний досвід у закладах освіти та спостереження дозволяють стверджувати, що найчастіше увагу до обдарованих дітей привертає їх великий словниковий запас, а також уміння ставити запитання. Багато обдарованих дітей із задоволенням читають словники та енциклопедії, вигадують слова, віддають перевагу іграм, які потребують розумового напруження. Обдарованих дітей також вирізняє підвищена концентрація уваги на будь-чому, наполегливість у досягненні результату в тій сфері, яка їх цікавить.

Павлиський учитель наголошує, що одна 3 найважливіших проблем закладів освіти - це поглиблення інтелекту дитини, розвиток іiі розуму. А це - розвиток образного й логіко-аналітичного мислення, усунення його уповільненості: «... дитину потрібно готувати до найголовнішої праці людського життя до серйозної, наполегливої ... праці, яка неможлива без напруження думки» [5, с. 111].

Василь Олександрович прагнув, щоб розум і талановитість стали основою успіхів у навчанні, щоб кожен учень не навчався нижче від своїх здібностей. Ось чому педагог постійно шукає різноманітні форми організації навчального процесу та форми навчальної діяльності учнів, оригінальні методи, значну кількість 3 яких доцільно впроваджувати у новій українській школі.

На глибоке переконання педагога, розкриття задатків багато в чому залежить від спілкування, яке відбувається між дитиною і педагогом. Він визначає людське спілкування як «надзвичайно широке, багатогранне задоволення потреби людини в людині» [6]. Він уважає, що праця педагога повинна бути спрямована також на піклування про здоров'я і фізичне виховання дитини.

Діти мають виявляти інтерес до діяльності, що вимагає тонкої і точної моторики; добре володіти зорово-моторною координацією; любити рух; мати широкий діапазон рухів (від повільних до швидких, від плавних до різких); прекрасно володіти тілом під час маневрування; для свого віку володіти винятковою фізичною силою, демонструвати хороший рівень розвитку основних рухових навичок.

Василь Олександрович велику увагу приділяє питанню стимулювання в дітей бажання вчитися. Педагогу необхідно створювати в учнів внутрішній стан емоційної піднесеності, інтелектуальної наснаги, інакше знання викликають тільки байдужість, розумова праця приносить втому, а це, відповідно, негативно відображається на працездатності всього організму в цілому. Для запобігання появи цих негативних наслідків В. Сухомлинський створює такі ситуації, в яких дитина відчуває себе успішною, він намагається захопити дитину тим, що їй цікаво і від чого вона отримує задоволення та радість.

Педагог-новатор застосовує «техніку управління пам'яттю». Однією із форм закріплення орфографічного мінімуму $є$ методика, розроблена Павлиським педагогом, що має назву «шістсот «казкових» слів».

У молодших класах навчання та розумова праця весною має бути зовсім не такою, як в осінню пору, стверджує вчений. Розумова праця в останній чверті, що припадає на весну, повинна включати в себе зазвичай ті види роботи, які розвивають, поглиблюють, систематизують набуті знання. Весною необхідно накопичувати факти для теоретичного узагальнення в наступному навчальному році.

У своїй педагогічній діяльності Василь Сухомлинський використовує різні форми роботи, зокрема форми повторного пояснення вже вивченого раніше, щоб найсильніший учень знаходив щось цікаве, нове для себе, натомість там, де немає ніяких прогалин у знаннях, педагог вдається до скороченого пояснення. 
Таку форму добування знань він називає «екскурсом школяра у власні думки», «дослідженням своєї комори знань».

Ретельне вивчення педагогічних ідей ученого та ïх переосмислення й упровадження дозволять будувати освітній процес нової української школи на засадах успіху та радості для кожної дитини.

Висновки та перспективи подальших наукових досліджень. Учений-практик неабиякого значення надавав питанню стимуляції в дітей бажання вчитися. Він створював такі ситуації, в яких дитина відчувала себе успішною; намагався захопити дитину тим, що їй цікаве. Під час навчання враховував закономірності розвитку дитячого організму. Означене надає можливість кожній дитині відчути радість успіху в навчанні, що $\epsilon$ необхідною умовою комфортної і продуктивної навчальної діяльності нової української школи.

\section{СПИСОК ВИКОРИСТАНОЇ ЛІТЕРАТУРИ}

1. Сухомлинський В. О. Вибрані твори : в 5 т. Т. 1. Проблеми виховання всебічно розвиненої особистості.
Духовний світ школяра. Методика виховання колективу / В. О. Сухомлинський. - К. : Радянська школа, 1976. -654 c.

2. Сухомлинський В. О. Вибрані твори : в 5 т. Т. 2. Формування комуністичних переконань молодого покоління. Як виховати справжню людину. Сто порад учителеві / В. О. Сухомлинський. - К. : Радянська школа, 1976. - 661 с.

3. Сухомлинський В. О. Вибрані твори : в 5 т. T. 3. Серце віддаю дітям. Народження громадянина. Листи до сина / В. О. Сухомлинський. - К. : Радянська школа, 1977. - 670 с.

4. Сухомлинський В. О. Вибрані твори : в 5 т. T. 4. Павлиська середня школа. Розмова 3 молодим директором / В. О. Сухомлинський. - К. : Радянська школа, 1977. - 640 с.

5. Сухомлинський В. О. Вибрані твори : в 5 т. Т. 5. Статті / В. О. Сухомлинський. - К. : Радянська школа, 1977. - 639 с.

6. Сухомлинський В. О. Серце віддаю дітям / В. О. Сухомлинський. - К. : Рад. шк., 1968. - 198 с.

Дата надходження до редакиіï: 25.07.2019 p.

Любов ТАРАБАСОВА, кандидатка філософських наук, дочентка кафедри дошкільної та початкової освіти КЗВО «Дніпровська академія неперервної освіти» Дніпропетровської обласної ради, м. Дніпро

Наталія ОЛЕФІР, старша викладачка кафедри дошкільноі та початкової освіти КЗВО «Дніпровська академія неперервної освіти» Дніпропетровської обласної ради, м. Дніпро

\section{ГУМАНІСТИЧНІ ТЕНДЕНЦЇ̈ В ДОШКІЛЬНІЙ ОСВІТІ: ТЕОРЕТИКО-МЕТОДОЛОГІЧНЕ ДОСЛІДЖЕННЯ}

\begin{abstract}
У статті розглянуто питання гуманізації в освітньому процесі дітей дошкільного віку. З'ясовано та проаналізовано гуманістичні тендениії в теоріі та практиці вітчизняних $і$ зарубіжних науковців та педагогів. Визначено основні положення гуманістичного підходу щсодо виховання дітей.

Ключові слова: гуманістичний освітній простір, зона найближчого розвитку, особистісно орієнтований підхід, принции гуманістичного спрямування.

В статье рассмотрены вопросы гуманизации 6 образовательном прочессе детей дошкольного возраста. Выяснены и проанализированы гуманистическиетенденции в теории и практике отечественныхи зарубежных ученых, педагогов. Определены основные
\end{abstract}

положения гуманистического подхода к воспитанию детей.

Ключевые слова: гуманистическое образовательное пространство, зона ближайшего развития, личностно ориентированный подход, принции гуманистического направления.

The article deals with the issues of humanization in the educational process of preschool children. The humanistic tendencies in the theory and practice of domestic and foreign scientists and educators are analyzed and analyzed. The basic principles of the humanistic approach to the upbringing of children are determined.

A prerequisite for the humanist orientation of the individual is a positive attitude. Of great significance 